\title{
$\$$ Research Square

\section{Antimicrobial Activity of Bacteriocin Produced By a New Lactobacillus Curvatus sp.LAB-3H Isolated From Traditional Yogurt}

\section{Zahra Heidari}

Islamic Azad University of Lahijan

Mohammad Faezi Ghasemi ( $\square$ faezi_m@yahoo.com )

Islamic Azad University of Lahijan https://orcid.org/0000-0003-2188-176X

Leila Modiri

Islamic Azad University of Lahijan

\section{Research Article}

Keywords: Antimicrobial activity, Bacteriocin, Lactobacillus curvatus LAB-3H, Traditional Yogurt

Posted Date: August 31st, 2021

DOl: https://doi.org/10.21203/rs.3.rs-832575/v1

License: (c) (i) This work is licensed under a Creative Commons Attribution 4.0 International License.

Read Full License 


\section{Abstract}

In recent years, the use of bacteriocin-producing Lactobacillus species has received much attention in different areas including using as probiotics, food preservation, and as broad antimicrobial spectrum activity. In this study, a bacteriocin-producing Lactobacillus strain was isolated from traditional yogurt. The isolate was identified by morphological, biochemical,

16S rRNA analysis, and designated as Lactobacillus curvatus LAB-3H. The primary antimicrobial activity of the isolate was evaluated on Micrococcus luteus PTCC 1408 by the agar gel diffusion method. The growth of L. curvatus LAB-3H in MRS broth at $37^{\circ} \mathrm{C}$ and its antimicrobial activity against Lactobacillus casei ATCC 39392 was evaluated. In batch culture analysis, bacteriocin production starts at the early exponential growth phase and continues to the middle of the stationary phase about $(660 \mathrm{AU} / \mathrm{ml})$ at $28 \mathrm{~h}$ and $\mathrm{pH}$ 3.8. Bacteriocin produced by $\mathrm{L}$. curvatus $\mathrm{LAB}-3 \mathrm{H}$ showed antibacterial activity against some selected foodborne pathogens including; Listeria monocytogenes PTCC1294, Bacillus cereus PTCC1857, Staphylococcus aureus PTCC1917 and, Escherichia coli PTCC1276. For purification of bacteriocin, ammonium sulfate precipitation and cation exchange chromatography methods were used. The maximum antimicrobial activity observed was about $3985.15 \mathrm{AU} / \mathrm{mg}$ of protein, which was a 249.22-fold increase, and $5.21 \%$ yield compared with that in the cell-free supernatant. The molecular weight of bacteriocin was approximately $55 \mathrm{kDa}$ by SDS-PAGE. The obtained results in this study demonstrate that bacteriocin from L. curvatus $\mathrm{LAB}-3 \mathrm{H}$ is a potential candidate for controlling microbial contaminations and can be used in different sectors such as food industries.

\section{Introduction}

Dairy foods play an important role in the daily diet and contain nutrients for human health. It should be noted that not all dairy products have the same sources of nutrients. Yogurt is one of the most consumed dairy products in many countries such as Finland, France, Spain, and Germany. Vitamins, minerals, lactose-based carbohydrates, proteins, lipids, and live microbes

are important nutritional components of yogurt. Live lactic acid bacteria (LAB) lower the $\mathrm{pH}$ of yogurt by producing lactic acid and other organic acids, and maintain the stability of yogurt. In yogurt, lactose utilizes by the lactase activity of LAB bacteria as starter microorganisms. Therefore, in comparison to milk, yogurt has lower lactose and lactose-intolerant individuals can easily consume it. Because of these important reasons, yogurt is usually considered in most food dietary programs. (Drewnowski, 2018; Fisberg Machado, 2015; Gómez-Gallego et al., 2018; Weaver, 2014).

Amongst LAB bacteria, Lactobacillus curvatus has been considered a probiotic candidate due to its fermentation and health benefits. L. curvatus was included in the Catalogue of Microorganisms with Technical Necessity in Fermented Food" in the Bulletin of the International Dairy Federation in 2012 and recommended as a biological agent in the European Food Safety Administration Qualification Certification in 2013. Recently, L. curvatus has been approved by the government of China as a new food 
raw material for processing meat, dairy, and fish products (Bourdichon et al., 2012; Chen et al., 2020; Hazards, 2013).

L. curvatus is one of the bacterial species in fermented meat, and it can be easily isolated from meat products. This species has also been isolated from dairy and fermented plant products such as milk and cheese, kimchi, sourdough, and honey. Troili first described L. curvatus under the name Bacterium curvatum in 1903. Abo-Elnaga and Kandler described this species, and they renamed L. curvatus from Bacterium curvatum in 1965. Zheng et al. 2020, updated the name of L. curvatus to Latilactobacillus curvatus. From a taxonomic point of view, L. curvatus is closely related to Latilactobacillus sakei (Chaillou et al., 2015; Chen et al., 2020; Lucquin et al., 2012; Zheng et al., 2020).

L. curvatus produce class II bacteriocins such as Curvacin A and Sakacins P, which can inhibit pathogenic bacteria including L. monocytogenes, S. aureus, and E.coli. Purification and characterization of Curvacin A from L. curvatus LTH1174 was performed by Tichaczed et al. in 1992. Also, Hebert et al. 2012 reported the whole genome sequence of L. curvatus strain CRL705 (de Souza Barbosa et al., 2015; Hebert et al., 2012; Tichaczek et al., 1992).

By the year 2020, the genome of 24 strains of L. curvatus had been sequenced and deposited in the National Center for Biotechnology Information (NCBI) database. According to the genomic data, $L$. curvatus has many genes related to carbohydrate metabolic pathways, such as glucose and trehalose metabolism. In addition, these data indicate that L. curvatus has diverse genes related to bacteriocin production (Chen et al., 2020; Eisenbach et al., 2018; Terán et al., 2018).

Bacteriocins are ribosomally synthesized peptides by lactic acid bacteria (LAB); these peptides are considered natural preservatives or bio preservatives that fulfill these requirements. The antimicrobial effects of $L A B$ bacteria are attributed to these bacteriocins, which can inhibit or destroy undesired microorganisms to enhance shelf life and food safety.

Three methods are commonly used in the application of bacteriocins for biopreservation of foods: 1) inoculation of food with LAB that produces bacteriocin in the products, 2) addition of purified or semipurified bacteriocins as food preservatives and, 3) use of a product previously fermented with a bacteriocin-producing strain as an ingredient in food processing

(Ahn et al., 2017; Castro et al., 2011).

L. curvatus has been isolated from fermented and vacuum-packaged refrigerated meat, fish and dairy products such as milk and cheese. (Kask et al., 2003; Michel et al., 2016; Nakano et al., 2016). Recently L. curvatus has been identified in fermented plant products such as sourdough and radish pickles (Chaillou et al., 2015; Lucquin et al., 2012; Terán et al., 2018).

Although there are some reports regarding isolation and identification of L. curvatus from different sources, to the best of our knowledge there's little information regarding isolation and characterization of L. curvatus from traditional yogurt. The aim of this study is the isolation, characterization of L. curvatus 
from traditional yogurt, evaluation of bacteriocin production, purification, and assessing the antimicrobial activity against some selected food-borne pathogens.

\section{Materials And Methods}

\section{Samples, isolation of Lactobacillus strains, foodborne pathogens, media, and growth conditions}

All media and materials used in this study were obtained from (Merck Co. Darmstadt, Germany). For isolation of Lactobacillus strains, 50 samples of yogurt $(0.5 \mathrm{~kg}$ each) were obtained from local vendors in Rasht city, Guilan province, Iran. $50 \mathrm{~g}$ of each sample was placed into sterile stomacher bags and then were diluted (1:10) with MRS broth, processed to enrich the LAB by stomaching, sealed, and incubated overnight at $30^{\circ} \mathrm{C}$.

Lactic acid bacteria were isolated by 5 -fold serial dilutions. At first, $1 \mathrm{~mL}$ of sample in stomacher bags was added to $9 \mathrm{~mL}$ of sterile $(0.90 \% \mathrm{NaCl})$ and then serially diluted. Then, $0.1 \mathrm{~mL}$ aliquots of each sample were plated onto MRS agar. The plates were incubated at $37^{\circ} \mathrm{C}$ for $24-48 \mathrm{~h}$ in anaerobic jars using the AnaeroGen anaerobic system (Oxoid, Thermo Fisher Scientific, USA) in microaerobic conditions $\left(5 \% \mathrm{CO}_{2}\right)$. MRS agar plates were used to identify the initial growth of the LAB in each sample. The resulting isolates were randomly selected and were streaked twice on fresh MRS agar for obtaining purified colonies. The isolated strains were maintained by culturing them in MRS broth medium at $30^{\circ} \mathrm{C}$ and then storing them at $-80{ }^{\circ} \mathrm{C}$ in MRS broth containing 50\% (v/v) glycerol for further studies (Bin Masalam et al., 2018; Bosch et al., 2012; Kargozari et al., 2015).

Micrococcus luteus PTCC 1408 was used as an indicator for primary evaluating the antimicrobial susceptibility tests. Lactobacillus casei ATCC 39392 was used for the evaluation of antimicrobial activity in submerged culture conditions. Also, Foodborne pathogens including Listeria monocytogenes PTCC1294 (native strain), Bacillus cereus PTCC1857 (native strain), Staphylococcus aureus ATCC 29213 and, Escherichia coli PTCC1276 (native strain) were used for evaluation of the antimicrobial activity of produced bacteriocin by the isolated strain. All bacteria were obtained from Persian Type Culture Collection (PTCC, Tehran, Iran).

\section{Phenotypic, biochemical, and molecular characterization of the isolates}

For identification and characterization of the LAB isolates, phenotypic characterization including Gram staining, colony size, and morphology, biochemical tests such as carbohydrate fermentation, catalase activity, growth at $15^{\circ} \mathrm{C}$ and $45^{\circ} \mathrm{C}$, growth at $4 \%$ and $6.5 \% \mathrm{NaCl}$, and motility were carried out according to the Bergey's Manual of Systematic Bacteriology (Vos et al., 2011).

For taxonomic characterization of L. curvatus isolate, the 16S rRNA analysis was performed. The genomic DNA was extracted from single colonies of the bacterial strains, using Qiagen DNeasy blood and tissue kit (QIAGEN N.V, Germany) (following the manufacturer's instructions). The bacterial 16S rRNA loci were amplified using the forward 
1505r: 5'- GATACGGCTACCTTGTTACGA -3' primers. The PCR program was performed in a Techne FTC51S5D Thermocycler (Staffordshire, UK) for 35 cycles under the following temperature profile: $95^{\circ} \mathrm{C}$ for $3 \mathrm{~min}(1 \mathrm{cycle}) ; 93^{\circ} \mathrm{C}$ for $45 \mathrm{~s}, 58^{\circ} \mathrm{C}$ for $1 \mathrm{~min}$ and $72{ }^{\circ} \mathrm{C}$ for $90 \mathrm{~s}$ ( 35 cycles); and $72^{\circ} \mathrm{C}$ for $10 \mathrm{~min}$ at the end of the final cycle. The PCR product was purified using a GF-1 PCR Cleanup kit (Vivantis technologies, Malaysia). The purified products were sequenced using the following primers:

27f: 5'-GAGTTTGATCCTGGCTCAG -3', 16r339: 5'- ACTGCTGCCTCCCGTAGGAG -3'

16f358: 5'- CTCCTACGGGAGGCAGCAG-3', 704f: 5'- GTAGCGGTGAAATGCGTAGA- 3'

1505r: 5'- GATACGGCTACCTTGTTACGA -3'

The Sanger's dideoxy chain-termination sequencing method was applied using an ABI 3730XL DNA analyzer (Thermo Fisher Scientific Inc. USA). The similarities between 16S rRNA sequences were compared in the National Center for Biotechnology Information

(NCBI), Ribosomal Data Base and EzTaxon databases. The phylogenetic tree based on 16S rRNA gene sequence was constructed against different related Lactobacillus strains according to partial sequence analysis. The evolutionary distances were computed using the Maximum Composite Likelihood method and are in the units of the number of base substitutions per site. This analysis involved 28 nucleotide sequences. All positions with less than $95 \%$ site coverage were eliminated, i.e., fewer than $5 \%$ alignment gaps, missing data, and ambiguous bases were allowed at any position (partial deletion option). There were a total of 1478 positions in the final dataset. Phylogenic dendrograms were generated through the neighbor-joining method with bootstrap test (1,000replicates) using MEGA X (Molecular Evolutionary Genetics Analysis software version 10.1.) (Kumar et al., 2018; Tamura et al., 2004).

\section{Evaluation of bacteriocin production by $L$. curvatus LAB-3H}

The growth kinetics and antimicrobial activity of bacteriocin produced by the selected

L. curvatus strain LAB-3H was evaluated using an MRS broth medium. $250 \mathrm{~mL}$ of MRS broth at $\mathrm{pH} 6.8$ was inoculated with $(1 \% \mathrm{v} / \mathrm{v})$ cell suspension of $L$. curvatus $L A B-3 \mathrm{H}$ and incubated at $37^{\circ} \mathrm{C}$ without agitation; in the presence of nitrogen for $48 \mathrm{~h}$. Bacterial cell density, antimicrobial activity against the indicator strain L. casei ATCC 39392, and pH were measured every 4 hours during fermentation.

\section{Determination of the antibacterial activity of produced bacteriocin by L. curvatus LAB-3H against selected foodborne pathogens}

For the determination of the antibacterial activity of produced bacteriocin by L. curvatus LAB-3H against selected foodborne pathogens, the method of (Thirumurugan et al., 2013) was used. L. curvatus LAB-3H was grown in MRS broth (Merck Co. Darmstadt, Germany) at pH 6.8 and maintained aerobically at $35^{\circ} \mathrm{C}$ for $48 \mathrm{~h}$. Then, bacterial cells were removed from the growth medium by centrifugation $(10000 \mathrm{X} \mathrm{g}$ for 30 
min at $\left.4^{\circ} \mathrm{C}\right)$ and passed through the Whatman membrane filter $(0.2 \mu \mathrm{m}$ diam. $47 \mathrm{~mm})$. The cell-free supernatant was with adjusted $\mathrm{pH} 6.0$ using $1 \mathrm{~N} \mathrm{NaOH}$ and used as crude bacteriocin. Bacteriocin activity was determined by the agar well diffusion method. At first, suspension of four foodborne pathogens including L. monocytogenes PTCC1294, B. cereus PTCC1857, S. aureus ATCC 29213 and,

E. coli PTCC1276 were prepared using turbidity standard McFarland 0.5 . Then, $150 \mu \mathrm{L}$ of these suspensions were inoculated onto the medium by the streaking plate method, and four wells were punched in each inoculated agar medium plate using a sterile Cork borer (6mm diameter). Then, $100 \mu \mathrm{L}$ aliquots of prepared cell-free extract of $L$. curvatus $\angle A B-3 H$ were pipetted into their designated wells on the plates. All inoculated plates were incubated at $37^{\circ} \mathrm{C}$ for $18-24 \mathrm{~h}$. The diameter of each inhibition zones was measured twice using a ruler; then, the average was taken to represent the antibacterial activity (Bin Masalam et al., 2018; Thirumurugan et al., 2013). The activity of cell-free supernatant was explained in arbitrary units per $\mathrm{ml}(\mathrm{AU} / \mathrm{ml})$. A unit activity of the bacteriocin was defined as an arbitrary unit (Mathur et al., 2017); 1 AU is a unit area of inhibition zone per unit volume, in this case, $\mathrm{mm} 2 / \mathrm{ml}$ (Usmiati Marwati, 2009). The bacteriocin activity was calculated using the following formula: Bacteriocin activity $(\mathrm{mm} 2 / \mathrm{ml})$ $=\mathrm{Lz}-\mathrm{Ls} / \mathrm{V}$ which the parameters are LZ=clear zone area $(\mathrm{mm} 2), \mathrm{Ls}=$ well area $(\mathrm{mm} 2)$, and $V=$ volume of the sample (ml) (Bin Masalam et al., 2018).

\section{Determination of minimum inhibitory concentration}

For the determination of minimum inhibitory concentration, the standard broth dilution method for the crude bacteriocin, and selected antibiotics was used in 70192 Mueller Hinton broth (Sigma-Aldrich) medium, according to CLSI M7-A8 and M100-S28-2018 guidelines. Serial two-fold dilution (50, 25, 12.5, $6.25,3.125,1.56,0.78$ and $0.39 \mu \mathrm{g} / \mathrm{ml})$ of the cell-free extract of bacteriocin, and antibiotics $(64,32,16,8$, 4,2 and $1 \mu \mathrm{g} / \mathrm{ml}$ ) with adjusted bacterial concentration (108 CFU/ml $0.5 \mathrm{McFarland}$ 's standard) were used to determine MIC in $\mathrm{MH}$ broth. The control contained only inoculated broth and was incubated for $24 \mathrm{~h}$ at $37^{\circ} \mathrm{C}$. The MIC endpoint is the lowest concentration of antimicrobial components where no visible growth is seen in the tubes. The visual turbidity of the tubes was distinguished, both before and after incubation to approve the MIC value.

\section{Purification of bacteriocin produced by L. curvatus LAB-3H}

Bacteriocin produced by L. curvatus LAB-3H was purified using a two-step procedure, including ammonium sulfate precipitation and cation-exchange chromatography suggested by

(Srinivasan et al., 2013; Zhang et al., 2018) with some modifications.

L. curvatus strain LAB-3H was inoculated in 1-liter MRS broth and incubated at $37^{\circ} \mathrm{C}$ for $20 \mathrm{~h}$. Cells were discarded by centrifugation at 12,000 rpm for $5 \mathrm{~min}$. Then, cell-free supernatant was subsequently precipitated using $45,55,65,75$, and $85 \%$ ammonium sulfate, after that the precipitates were collected by centrifugation at $10000 \mathrm{rpm}$ for $20 \mathrm{~min}$ and dissolved in double-distilled water. The dissolved proteins 
were filtered through a $0.22-\mu \mathrm{m}$ filter and dialyzed using a $1000 \mathrm{Da}$ cut-off membrane (Solarbio, China). The AKTA purifier (GE Healthcare, Uppsala, Sweden), equipped with an SP Sepharose Fast Flow column, was used for further purification of the bacteriocin protein. The system was equilibrated with $50 \mathrm{mmol} / \mathrm{L}$

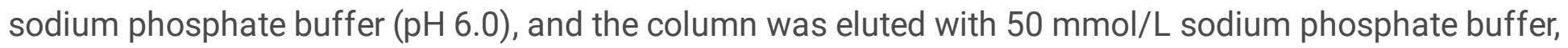
containing $1 \mathrm{~mol} / \mathrm{L} \mathrm{NaCl}$, at a flow rate of $2 \mathrm{~mL} / \mathrm{min}$. The elution procedure was monitored by a UV detector at $280 \mathrm{~nm}$. Fractions with the maximum antimicrobial activity were collected and identified (Srinivasan et al., 2013).

\section{SDS-PAGE analysis}

SDS-PAGE analysis of purified bacteriocin was performed with $16 \%$ resolving gel and $10 \%$ stacking gel. The gel was cut into two parts: (i) gel was stained with Coomassie brilliant blue R-250 to determine the molecular size of bacteriocin and (ii) another gel was fixed in $20 \%(\mathrm{v} / \mathrm{v})$ isopropanol and $10 \%(\mathrm{v} / \mathrm{v})$ acetic acid for $2 \mathrm{~h}$, and rinsed in sodium phosphate buffer $(\mathrm{pH} 6.0)$ for $1 \mathrm{~h}$. After that, the gel was overlaid with a soft agar medium inoculated with the indicator strain for $48 \mathrm{~h}$.

\section{Statistical Analysis}

In this study, all data were expressed as mean \pm standard deviation (SD) of triplicate independent experiments. All statistical analyses were performed with SPSS/PC software, version 20.0.

\section{Results}

In this study, 30 Lactobacillus strains were isolated from traditional yogurt samples. Based on macroscopic and microscopic characteristics, all isolates were Gram-positive long and slender bacilli or bent and short often-coryneform coccobacilli. According to the primary antibacterial activity screening, 10 strains showed observable antibacterial activity, and amongst them the isolate LAB-3H showed the highest antibacterial activity based on the agar well method as shown in Fig. 1 (A) and (B), significant zones of inhibition were observed against

M. Iuteus PTCC 1408 grown on Mueller-Hinton agar medium. Phenotypic and biochemical characteristics of the 10 isolates were presented in Table 1. According to phenotypic and biochemical tests, the Lactobacillus strains with higher antibacterial activity including $L A B-2 \mathrm{H}, \mathrm{LAB}-3 \mathrm{H}$, and LAB-4H were resembled L. equi, L. curvatus, and L. fuchuensis, respectively.

For LAB-2H, LAB-3H, and LAB-4H isolates, 16S rRNA gene amplification, were performed as shown in Fig. 2. For all three strains, a sequence of about 1500 nucleotides was obtained. The analysis of the obtained sequence for $\mathrm{LAB}-3 \mathrm{H}$ showing about $99 \%$ sequence coverage to

L. curvatus strain CBA-3617(complete genome), L. curvatus strain TMW1.1928 (complete genome), L. curvatus strains JCM 1096 (complete genome), L. curvatus strain 1TP08-BL02 (16S rRNA partial sequence), and L. curvatus strain B515 (16S rRNA partial sequence), respectively according to the blast comparison in the NCBI database. The phylogenetic tree based on 16S rRNA partial gene sequence for 
LAB-3H isolate is shown in Fig. 3. The nucleotide sequence of the isolate $L$. curvatus $L A B-3 H$ was deposited in the GenBank database with the accession number MW314018.1 and presented in the red format in the tree.

Table 1

Phenotypic and biochemical characteristics of native LAB strains isolated from traditional yogurt $\begin{array}{llllllllllll}\text { Characteristics } & 1 \mathrm{H} & 2 \mathrm{H} & 3 \mathrm{H} & 4 \mathrm{H} & 5 \mathrm{H} & 6 \mathrm{H} & 7 \mathrm{H} & 8 \mathrm{H} & 9 \mathrm{H} & 10 \mathrm{H} & \begin{array}{l}\text { Lactobacillus } \\ \text { casei }\end{array}\end{array}$

ATCC 39392

Growth $\left({ }^{\circ} \mathrm{C}\right)$ at $\quad-/-\quad-/+\quad+/-\quad+/-\quad+/+\quad+/-\quad+/+\quad+/+\quad+/-\quad-/+\quad+/-$ $15 / 45$

Growth in

$\mathrm{NaCl}$

$\begin{array}{llllllllllll}4.0 \% & - & - & - & - & + & + & + & + & + & + & - \\ 6.5 \% & - & - & - & - & - & - & + & + & - & - & - \\ \text { Catalase } & - & - & - & - & - & - & - & - & - & - & - \\ \text { Motility } & - & - & - & - & - & + & - & - & - & + & -\end{array}$

\section{Carbohydrates}

Fermentation

\begin{tabular}{llllllllllll} 
Amygdalin & - & - & $\mathrm{d}$ & + & + & - & - & - & + & + & + \\
Arabinose & - & + & - & - & - & - & - & + & + & - & - \\
Cellobiose & + & - & + & + & - & - & - & + & + & - & + \\
Esculin & - & - & + & + & + & + & - & - & - & - & + \\
Gluconate & - & - & - & + & + & + & + & - & - & + & + \\
Mannitol & + & + & - & - & - & + & + & + & + & - & + \\
Melezitose & - & + & - & - & - & - & - & + & - & - & + \\
Melibiose & - & + & - & - & + & - & + & + & + & - & - \\
Raffinose & - & - & - & - & - & + & + & + & - & - & - \\
Ribose & - & - & + & + & + & + & - & - & - & - & + \\
Sorbitol & - & - & - & - & + & - & - & - & - & - & + \\
Sucrose & - & - & $\mathrm{d}$ & - & + & - & + & + & + & - & + \\
Xylose & - & + & - & - & + & + & + & + & + & - & - \\
\hline
\end{tabular}


a Symbols and abbreviations:,$+ 90 \%$ or more of strains are positive;,$- 90 \%$ or more are negative; $d, 11-$ $89 \%$ of strains are positive; $w$, weak positive reaction; ND, no data available

M. luteus PTCC 1408

1. Front view of the plate and (B) back view of the plate

(LAB-3H), L7 and L8 lanes (LAB-4H).

Figure 4 shows the growth of L. curvatus $L A B-3 \mathrm{H}$ in MRS broth at $37^{\circ} \mathrm{C}$ and its antimicrobial activity against $L$. casei ATCC 39392, based on sampling and assessing agar gel diffusion assay. As shown, the bacteriocin activity is proportional to the bacterial cell growth. The dependence of bacteriocin production on bacterial growth shows that it could be a primary metabolite. The bacteriocin production starts at the early exponential growth phase and continues to the middle of the stationary phase about $(660 \mathrm{AU} / \mathrm{ml})$ at $28 \mathrm{~h}$ and $\mathrm{pH} 3.8$. The antimicrobial activity of bacteriocin decreased about $15 \%$ after $40 \mathrm{~h}$ of incubation.

\section{Determination of minimum inhibitory concentration}

The minimal inhibitory concentrations of the crude bacteriocin produced by L. curvatus LAB-3H against some selected foodborne pathogens in comparison with the reference antibiotics are summarized in Table 2. Minimum inhibitory concentrations of bacteriocin against

L. monocytogenes PTCC 1294, B. cereus PTCC 1857, S. aureus PTCC1917, and E. coli PTCC1276 were > $12.5,25,>25$, and $12.5 \mu \mathrm{g} / \mathrm{l}$, respectively.

\section{Partial purification of bacteriocin}

For purification, the cell-free supernatant was precipitated using $45,55,65,75$, and $85 \%$ ammonium sulfate. The results showed that $85 \%$ ammonium sulfate enhanced the antimicrobial activity by 4.53 -fold with a 45\%yield as shown in Table 3. In the next step, the precipitates by ammonium sulfate were purified by cation-exchange chromatography using an SP Sepharose Fast Flow column. Elution profile of SP Sepharose Fast Flow column for bacteriocin purification shown in Fig. 5. The fractions between 65-80 showed maximum antibacterial activity against $L$. casei ATCC 39392. The antimicrobial activity in these fractions was $3985.15 \mathrm{AU} / \mathrm{mg}$ of protein, which was a 249.22 -fold increase, and $5.21 \%$ yield compared with that in the cell-free supernatant (Nakano et al.). The results of SDS-PAGE analysis showed bands in the stained gel. The molecular mass of protein was found to be approximate 55KDa as shown in Fig. 6 . 
Table 2

Minimum inhibitory concentration (MIC) Bacteriocin produced by L. curvatus LAB-3H and reference antibiotics against four selected foodborne pathogens $\left(\mu \mathrm{g} / \mathrm{mL}^{-1}\right)$

\begin{tabular}{|l|}
\hline Bacteriocin Ampicillin Gentamycin Chloramphenicol \\
\hline L. monocytogenes PTCC1294 >12.5 $22^{\text {a NT }}$ \\
\hline S. aureus ATCC $2921325^{\text {a NT } 48}$ \\
\hline B. cereus PTCC1857>25 32168 \\
\hline E. coli PTCC1276 12.5848 \\
\hline a NT, not tested \\
\hline
\end{tabular}

Table 3

Purification of bacteriocin produced by L. curvatus LAB-3H

\begin{tabular}{|lllllll|}
\hline $\begin{array}{l}\text { Purification } \\
\text { stages }\end{array}$ & $\begin{array}{l}\text { Volume } \\
\text { (Bourdichon et al.; } \\
\text { Kargozari et al.) }\end{array}$ & $\begin{array}{l}\text { Activity } \\
\text { (AU/mL) }\end{array}$ & $\begin{array}{l}\text { Total } \\
\text { Protein } \\
\text { (mg/ml) }\end{array}$ & $\begin{array}{l}\text { Specific } \\
\text { activity } \\
\text { (AU/mg } \\
\text { protein) }\end{array}$ & $\begin{array}{l}\text { Purification } \\
\text { fold }\end{array}$ & $\begin{array}{l}\text { Yield } \\
\text { (\%) }\end{array}$ \\
\hline $\begin{array}{l}\text { Cell free } \\
\text { supernatant }\end{array}$ & 500 & 82000 & 5128.12 & 15.99 & 1 & 100 \\
$\begin{array}{l}85 \% \text { ammonium } \\
\text { sulfate } \\
\text { precipitation }\end{array}$ & 60 & 37800 & 521.36 & 72.50 & 4.53 & 45 \\
\hline $\begin{array}{l}\text { Cation-exchange } \\
\text { chromatography }\end{array}$ & 5.5 & 9126 & 2.29 & 3985.15 & 249.22 & 5.21 \\
\hline
\end{tabular}

\section{Discussion}

In this study, 30 bacterial strains were isolated from 50 samples of local traditional yogurt. Based on microscopic and macroscopic evaluations, ten isolates showed similar characteristics to Lactobacillus (LAB) strains. All were, non-spore-forming long and slender, sometimes bent rods to short, often coryneform, Gram-positive coccobacilli. Colonies on MRS agar were small (2-5 mm) with entire margins, convex, smooth, glistening, and commonly opaque without pigment. Antibacterial activity of the isolated strains was evaluated against M. luteus PTCC 1408. Amongst the isolates, LAB-3H showed significant antibacterial activity against

M. Iuteus PTCC 1408. Based on the antibacterial activity, the isolate LAB-3H was selected for taxonomical, bacteriocin production and purification studies in detail. Based on the described results we obtained the isolated strain LAB-3 $\mathrm{H}$ belongs to the species Lactobacillus curvatus. The morphology of the colony was gray, circular, flat, with irregular margin, ground-glass appearance, and shiny with 1.5-2.0 
$\mathrm{mm}$ in size. As described, the most related species according to the NCBI blast were L. curvatus strain CBA3617 (complete genome), L. curvatus strain TMW 1.1928 (complete genome), L. curvatus JCM 1096 (complete genome), L. curvatus strain 1TP08-BL02 (16S rRNA partial sequence), and L. curvatus strain B515 (16S rRNA partial sequence) with sequence coverage about $99 \%$, respectively.

Bacteriocin production by L. curvatus LAB-3H was studied in batch culture in MRS broth, and its antibacterial activity was evaluated against $L$. casei ATCC 39392. As described in Fig. 4, significant antibacterial activity was detected in the exponential phase and it could be related to a primary metabolite. During the growth, Lactobacillus spp. produce other metabolites such as lactic acid and hydrogen peroxide, and for ensuring that antibacterial activity does not relate to these metabolites, their effects were neutralized. Our experimental results showed that antimicrobial activity could be related to proteinaceous compounds (bacteriocin) secreted by L. curvatus LAB-3H into the extracellular culture medium. Bacteriocin, production by L. curvatus LAB-3H starts at early stationery and continues to the middle of the stationary phase (between 24 and $30 \mathrm{~h}$ after the start of fermentation) as mentioned for other bacteriocins. Maximum bacteriocin production by L. curvatus LAB-3H was observed at $28 \mathrm{~h}$ of incubation.

Usually, after reaching the stationary phase the loss of antimicrobial activity of bacteriocin occurs. There are some reasons for the loss of activity of bacteriocins in the stationary phase such as increasing the release of proteases in the extracellular environments, protein aggregation, and the degradation of bacteriocins upon aging of culture medium. In this study, after 40 hours of fermentation, a loss of bacteriocin activity about $15 \%$ was observed. A bacteriocin with an approximate molecular weight of 7.5 kDa was obtained from a native Lactobacillus acidophilus KS 400 obtained from Gynoflor R, Medinova AG, Switzerland, (Gaspar et al., 2018). They reported the loss of bacteriocin activity after the $32 \mathrm{~h}$ of the fermentation process.

Jiaje Ma et al. 2020 studied the growth dynamics and antimicrobial activity of L. casei KLDS 1.0338 against indicator strains. A lag phase from zero to $4 \mathrm{~h}$ was observed, and the bacterium reaches the end of the exponential phase after $20 \mathrm{~h}$ of incubation, the strongest antimicrobial activities against $S$. aureus ATCC 25923 and E. coli ATCC 25922 was observed in the stationary phase at $24 \mathrm{~h}$ of incubation. The approximate molecular mass of the bacteriocin produced by this strain was 6.8 kDa (Ma et al., 2020).

Usually, for bacteriocin production, high cell density does not guarantee higher bacteriocin activity due to the low production of bacteriocin by the bacterial cells. There is a relationship between environmental conditions and bacteriocin production. For some bacterial strains, there is a direct correlation between bacteriocin and biomass production, while for some other bacteria bacteriocin production only starts when the cells reach the stationary phase. The factors that affect bacteriocin production by Lactobacillus strains include, the producing strain, medium composition (carbohydrate and nitrogen sources, ions, etc.), fermentation conditions ( $\mathrm{pH}$, temperature, agitation, and aeration) as well and mode of fermentation (batch, fed-batch, and continuous fermentations) (Abbasiliasi et al., 2017). 
According to the obtained results in this study, lower minimum inhibitory concentrations of bacteriocin by L.curvatus LAB-3H were obtained against L. monocytogenes PTCC 1294 and

E. coli PTCC1276, respectively. In addition, the bacteriocin produced by this strain showed antibacterial activity against $B$. cereus PTCC 1857 and S. aureus PTCC1917.

Gasper et al. 2018 reported that bacteriocin produced by L. acidophilus KS 400, showed antibacterial activity against urogenital pathogens such as Gardnerella vaginalis, Streptococcus agalactiae, and Pseudomonas aeruginosa. A bacteriocin-producing Pediococcus acidilactici HW01 isolated from malt and the bacteriocin produced by this strain inhibited several Gram-positive bacteria, including $S$. aureus, S. mutans, L. curvatus, L. monocytogenes, and L. innocua (Ahn et al., 2017).

In a study by M. de Souza Barbosa, the antimicrobial activity of L.curvatus strains isolated from salami samples during the manufacturing of salami was studied against Listeria monocytogenes on a pilot scale. Two identified L.curvatus strains showed antimicrobial activity against $L$. monocytogenes strains. For bacteriocin MBSa2, antimicrobial activity was observed against 22 out of 23 L. monocytogenes strains, while the bacteriocin MBSa3 inhibited all 23 strains in addition to several other Gram-positive bacteria. A three-step purification procedure indicated that both strains produced the same two active peptides with a molecular weight of 4.45 and $4.36 \mathrm{kDa}$, homologous to sakacins $P$ and $X$, respectively (de Souza Barbosa et al., 2015).

Usually, the size described for Lactobacillus acidophilus bacteriocins ranges from 2.5 to $100 \mathrm{kDa}$ (Kim et al., 1998; Zamfir et al., 1999). Based on the obtained results in this study, the bacteriocin molecular weight produced by the isolate LAB-3H was about $55 \mathrm{kDa}$ in SAS-PAGE. This molecular weight is within the range of most reported bacteriocins by others. The molecular weight of bacteriocin produced by L.curvatus SE1 isolated from Kimchi was about 14 kDa (Kim et al. 1998). A bacteriocin-producing lacticacid bacterium was isolated from malt by H.Ahn et al. 2017. This isolate was identified as Pediococcus acidilactici, and the molecular weight of the crude bacteriocin was approximately $6 \mathrm{kDa}$ analyzed by the SDS-PAGE method (Kim et al., 1998; Zamfir et al., 1999).

A bacteriocin-producing Lactobacillus strain named Lactobacillus plantarum J23 was isolated from Chinese traditional fermented milk products. Three stages including $80 \%$ ammonium sulfate precipitation, cation-exchange chromatography, and reverse-phase high-performance liquid chromatography were used for the purification of bacteriocin Lac-B23 produced by this strain. The approximate molecular weight of bacteriocin Lac-B23 was determined about $6.73 \mathrm{kDa}$ using tricine sodium dodecyl sulfate-polyacrylamide gel electrophoresis analysis, and liquid chromatography-mass spectrometry confirmed it as a novel bacteriocin (Zhang et al., 2018).

The results obtained for purification of bacteriocin produced from LAB-3H isolate showed that $85 \%$ of ammonium sulfate increased the antibacterial activity by 4.53 - fold with $45 \%$ yield. 
It can be concluded that $85 \%$ ammonium sulfate could be used as an efficient method for bacteriocin purification, consistent with the results obtained by others. By further purification of produced bacteriocin by cation-exchange chromatography, we reached antibacterial activity about 249.22 -fold with a $5.21 \%$ yield. In this study, a bacteriocin-producing L. curvatus LAB-3H was isolated and identified out of 30 Lactobacillus strains from traditional yogurt samples. The antimicrobial activity of this native strain was evaluated against M. luteus PTCC 1408 and L. casei ATCC 39392 in primary screening ad submerged cultures, respectively. In addition, a bacteriocin produced by L.curvatus LAB-3H showed an inhibitory effect on selected foodborne pathogens including L. monocytogenes PTCC 1294, Bacillus cereus PTCC 1857, S. aureus PTCC1917, and E. coli PTCC1276. We could partially purify bacteriocin by two-step purification methods including $85 \%$ ammonium sulfate precipitation, cation-exchange chromatography.

It should be added that the recent increase of antibiotic resistance cases in pathogenic bacteria has encouraged scientists to reassess alternative therapeutic options such as combining antimicrobial agents such as bacteriocins with other compounds including nanomaterial and nanoparticles. Furthermore, combinations of bacteriocins with nanoparticles can decrease the concentration of bacteriocins required by the target pathogen (Heidari et al., 2020).

Therefore, we highly recommend further study of bacteriocin produced by L. curvatus LAB-3H to assess stability and elucidate its possible mechanism of action in different conditions in different sectors such as food industries as a preservative compound.

\section{Declarations}

\section{Acknowledgments}

The laboratory facilities for microbial experiments were provided by Lahijan Branch, Islamic Azad University, Lahijan, Iran.

\section{Author contribution}

This study was performed based on a Ph.D. thesis addressed to Zahra Heidari. ZH, MFG, and LM contributed almost equally to this study. MFG and LM designed the study, ZH did the experiments and performed research; MFG analyzed all data and wrote the paper.

\section{Funding}

This research did not receive any specific grant from funding agencies in the public, commercial, or notfor-profit sectors, and the authors financially supported this work.

\section{Compliance with ethical standards}

\section{Conflict of interest}

The author declares that they have no conflict of interest. 


\section{Data availability}

The GenBank accession number for the $16 \mathrm{~S}$ rRNA gene sequence of strain L. curvatus LAB-3H is MW314018.1.

\section{References}

1. Abbasiliasi S, Tan JS, Ibrahim TAT, Bashokouh F, Ramakrishnan NR, Mustafa S, Ariff AB (2017) Fermentation factors influencing the production of bacteriocins by lactic acid bacteria: a review. Rsc Advances 7(47):29395-29420

2. Ahn H, Kim J, Kim WJ (2017) Isolation and characterization of bacteriocin-producing Pediococcus acidilactici HW01 from malt and its potential to control beer spoilage lactic acid bacteria. Food Control 80:59-66

3. Bin Masalam MS, Bahieldin A, Alharbi MG, Al-Masaudi S, Al-Jaouni SK, Harakeh SM, Al-Hindi RR (2018) Isolation, molecular characterization and probiotic potential of lactic acid bacteria in Saudi raw and fermented milk. Evid-Based Compl Alt Med, 2018

4. Bosch M, Nart J, Audivert S, Bonachera MA, Alemany AS, Fuentes MC, Cuñé J (2012) Isolation and characterization of probiotic strains for improving oral health. Arch Oral Biol 57(5):539-549

5. Bourdichon F, Berger B, Casaregola S, Farrokh C, Frisvad J, Gerds M,.. . Laulund S (2012) Safety demonstration of microbial food cultures (MFC) in fermented food products. Safety Demonstration of Microbial Food Cultures (MFC) in Fermented Food Products. Bulletin of the International Dairy Federation 455:2

6. Castro MP, Palavecino N, Herman C, Garro OA, Campos CA (2011) Lactic acid bacteria isolated from artisanal dry sausages: characterization of antibacterial compounds and study of the factors affecting bacteriocin production. Meat Sci 87(4):321-329

7. Chaillou S, Chaulot-Talmon A, Caekebeke H, Cardinal M, Christieans S, Denis C,.. . Hamon E (2015) Origin and ecological selection of core and food-specific bacterial communities associated with meat and seafood spoilage. ISME J 9(5):1105-1118

8. Chen Y, Yu L, Qiao N, Xiao Y, Tian F, Zhao J,.. . Zhai Q (2020) Latilactobacillus curvatus: A Candidate Probiotic with Excellent Fermentation Properties and Health Benefits. Foods 9(10):1366

9. de Souza Barbosa M, Todorov SD, Ivanova I, Chobert J-M, Haertlé T, de Melo Franco B, D G (2015) Improving safety of salami by application of bacteriocins produced by an autochthonous Lactobacillus curvatus isolate. Food Microbiol 46:254-262

10. Drewnowski A (2018) Measures and metrics of sustainable diets with a focus on milk, yogurt, and dairy products. Nutr Rev 76(1):21-28

11. Eisenbach L, Janßen D, Ehrmann MA, Vogel RF (2018) Comparative genomics of Lactobacillus curvatus enables prediction of traits relating to adaptation and strategies of assertiveness in sausage fermentation. Int $\mathrm{J}$ of Food Microbiol 286:37-47 
12. Fisberg M, Machado R (2015) History of yogurt and current patterns of consumption. Nutr Rev 73(suppl-1):4-7

13. Gaspar C, Donders G, Palmeira-de-Oliveira R, Queiroz J, Tomaz C, Martinez-de-Oliveira J, Palmeira-deOliveira A (2018) Bacteriocin production of the probiotic Lactobacillus acidophilus KS400. Amb Express 8(1):1-8

14. Gómez-Gallego C, Gueimonde M, Salminen S (2018) The role of yogurt in food-based dietary guidelines. Nutr Rev 76(Supplement-1):29-39

15. Hazards EP o B (2013) Scientific Opinion on the maintenance of the list of QPS biological agents intentionally added to food and feed (2013 update). EFSA Journal, 11(11), 3449

16. Hebert EM, Saavedra L, Taranto MP, Mozzi F, Magni C, Nader MEF,.. . Raya RR (2012) Genome sequence of the bacteriocin-producing Lactobacillus curvatus strain CRL705. Am Soc Microbiol

17. Heidari Z, Faezi Ghasemi M, Modiri L (2020) The synergistic antibacterial effect of bacteriocin produced by Lactobacillus casei ATCC 39392 and iron oxide nanoparticles (IONPs) on selected foodborne pathogens. Int J Mol Clin Microbiol 10(1):1301-1311

18. Kargozari M, Emam-Djomeh Z, Gandomi H, Partovi R, Ghasemlou M, Martin IR (2015) Identification of selected Lactobacillus strains isolated from Siahmazgi cheese and study on their behavior after inoculation in fermented-sausage model medium. LWT-Food Sci Technol 62(2):1177-1183

19. Kask S, Adamberg K, Orłowski A, Vogensen FK, Møller PL, Ardö Y, Paalme T (2003) Physiological properties of Lactobacillus paracasei, L. danicus and L. curvatus strains isolated from Estonian semi-hard cheese. Food Res Int 36(9-10):1037-1046

20. Kim S-K, Lee E-J, Park K-Y, Jun H-K (1998) Bacteriocin produced by Lactobacillus curvatus SE1 isolated from Kimchi. J Mcrobiol Biotechnol 8(6):588-594

21. Kumar S, Stecher G, Li M, Knyaz C, Tamura K (2018) MEGA X: molecular evolutionary genetics analysis across computing platforms. Mol Biol Evol 35(6):1547

22. Lucquin I, Zagorec M, Champomier-Vergès $M$, Chaillou $S$ (2012) Fingerprint of lactic acid bacteria population in beef carpaccio is influenced by storage process and seasonal changes. Food Microbiol 29(2):187-196

23. Ma J, Yu W, Hou J, Han X, Shao H, Liu Y (2020) Characterization and production optimization of a broad-spectrum bacteriocin produced by Lactobacillus casei KLDS 1.0338 and its application in soybean milk biopreservation. Int J of Food Prop 23(1):677-692

24. Mathur H, Field D, Rea MC, Cotter PD, Hill C, Ross RP (2017) Bacteriocin-antimicrobial synergy: a medical and food perspective. Front Microbiol 8:1205

25. Michel E, Monfort C, Deffrasnes M, Guezenec S, Lhomme E, Barret M,.. . Onno B (2016) Characterization of relative abundance of lactic acid bacteria species in French organic sourdough by cultural, qPCR and MiSeq high-throughput sequencing methods. Int Journal Food Microbiol 239:35-43

26. Nakano K, Shiroma A, Tamotsu H, Ohki S, Shimoji M, Ashimine N,.. . Teruya K (2016) First complete genome sequence of the skin-improving Lactobacillus curvatus strain FBA2, isolated from fermented 
vegetables, determined by PacBio single-molecule real-time technology. Genome Announc 4(5):e00884-e00816

27. Srinivasan R, Kumawat DK, Kumar S, Saxena AK (2013) Purification and characterization of a bacteriocin from Lactobacillus rhamnosus L34. Ann Microbiol 63(1):387-392

28. Tamura K, Nei M, Kumar S (2004) Prospects for inferring very large phylogenies by using the neighbor-joining method. P Natl Acad Sci 101(30):11030-11035

29. Terán LC, Coeuret G, Raya R, Zagorec M, Champomier-Vergès M-C, Chaillou S (2018) Phylogenomic analysis of Lactobacillus curvatus reveals two lineages distinguished by genes for fermenting plantderived carbohydrates. Genome Biol Evol 10(6):1516-1525

30. Thirumurugan A, Ramachandran S, Shiamala Gowri A (2013) Combined effect of bacteriocin with gold nanoparticles against food spoiling bacteria-an approach for food packaging material preparation. Int Food Res J 20(4)

31. Tichaczek PS, Nissen-Meyer J, Nes IF, Vogel RF, Hammes WP (1992) Characterization of the bacteriocins curvacin A from Lactobacillus curvatus LTH1174 and sakacin P from L. sake LTH673. Syst Appl Microbiol 15(3):460-468

32. Usmiati S, Marwati T (2009) Selection and optimization process of bacteriocin production from Lactobacillus sp. Indones J Agric 2:82-92

33. Vos P, Garrity G, Jones D, Krieg NR, Ludwig W, Rainey FA,.. . Whitman WB (2011) Bergey's Manual of Systematic Bacteriology: Volume 3: The Firmicutes, vol 3. Springer Science \& Business Media

34. Weaver CM (2014) How sound is the science behind the dietary recommendations for dairy? The Am J Clin Nutr 99(5):1217S-1222S

35. Zamfir M, Callewaert R, Cornea PC, Savu L, Vatafu I, De Vuyst L (1999) Purification and characterization of a bacteriocin produced by Lactobacillus acidophilus IBB 801. J Appl Microbiol 87(6):923-931

36. Zhang J, Yang Y, Yang H, Bu Y, Yi H, Zhang L,... Ai L (2018) Purification and partial characterization of bacteriocin Lac-B23, a novel bacteriocin production by Lactobacillus plantarum J23, isolated from Chinese traditional fermented milk. Front Microbiol 9:2165

37. Zheng J, Wittouck S, Salvetti E, Franz CM, Harris H, Mattarelli P,.. . Walter J (2020) A taxonomic note on the genus Lactobacillus. Description of 23 novel genera, emended description of the genus Lactobacillus Beijerinck 1901, and union of Lactobacillaceae and Leuconostocaceae. Int J Syst Evol Microbiol 70(4):2782-2858

\section{Figures}




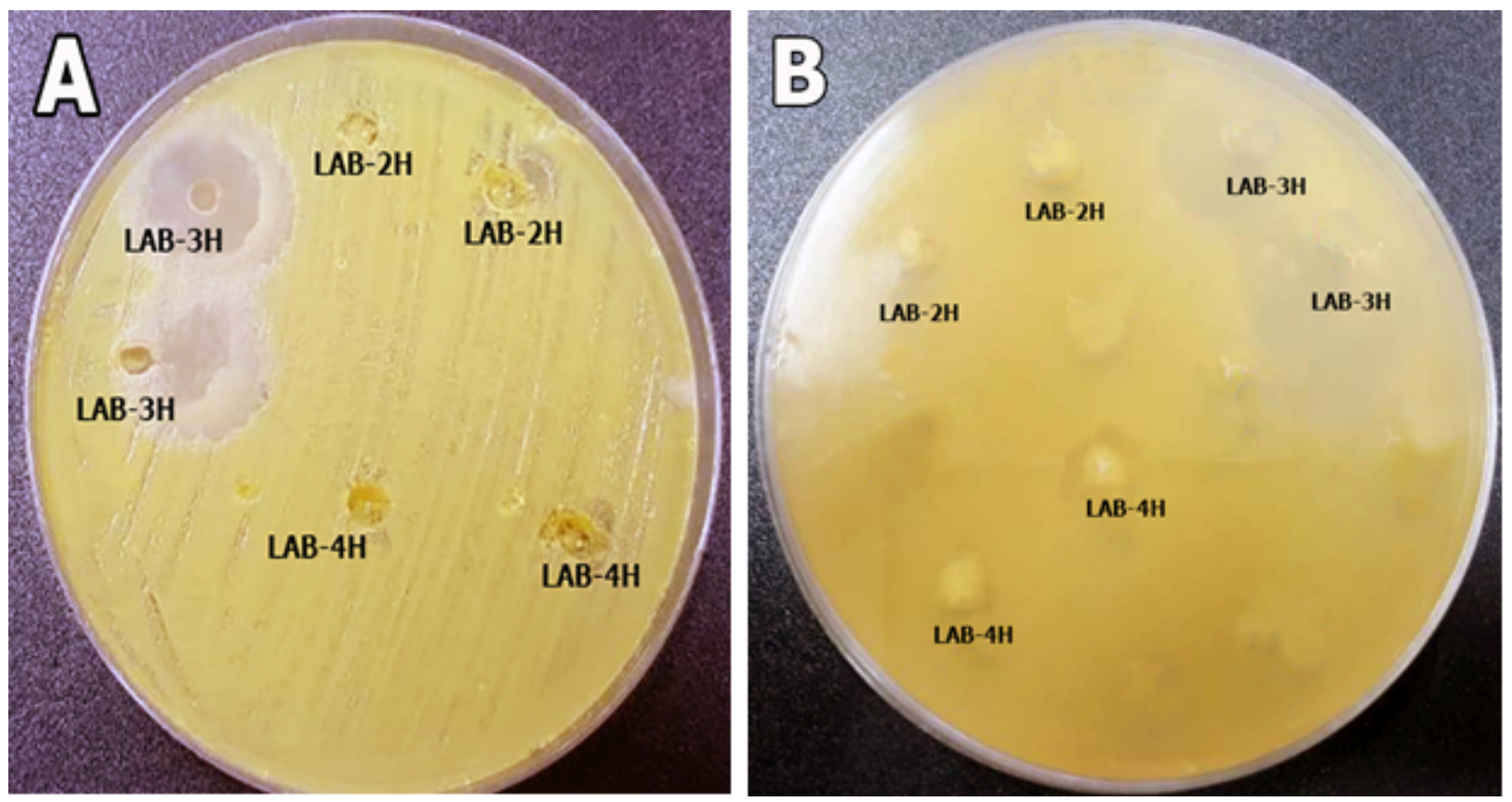

Figure 1

Antibacterial activity of Lactobacillus strains ( $L A B-2 \mathrm{H}, \mathrm{LAB}-3 \mathrm{H}$ and $\mathrm{LAB}-4 \mathrm{H})$ isolated from traditional yogurt grown on Mueller-Hinton agar against M. luteus PTCC 1408 (A) Front view of the plate and (B) back view of the plate

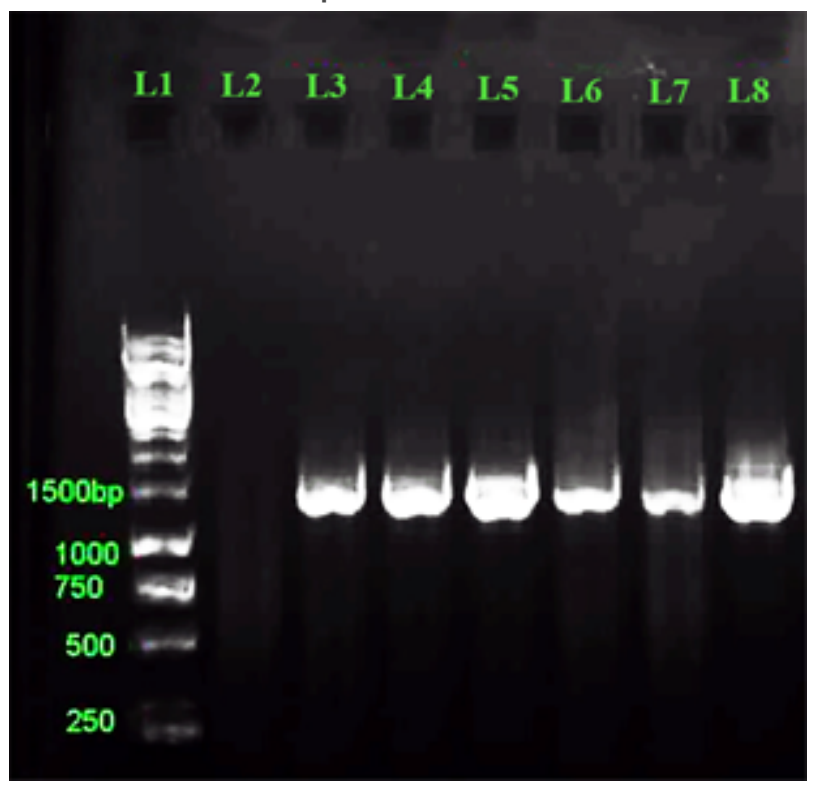

\section{Figure 2}

Agarose gel electrophoresis of amplified 16S rRNA gene PCR products of LAB-2H, LAB-3H and LA-4H isolates. L1 lane $1 \mathrm{~kb}$ DNA ladder, L2 lane negative control, L3 and L4 lanes (LAB-2H), L5 and L6 lanes (LAB-3H), L7 and L8 lanes (LAB-4H). 


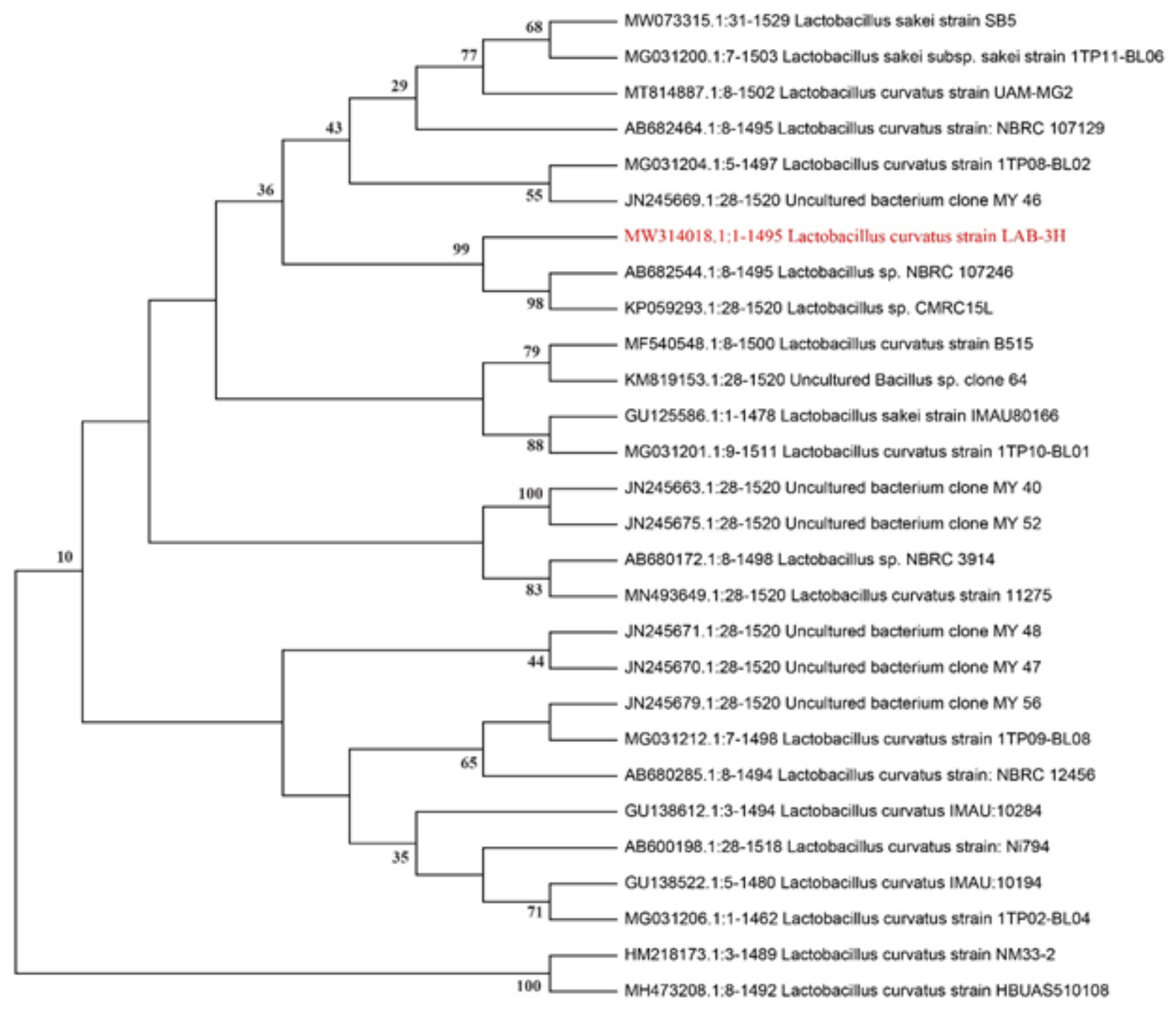

Figure 3

Neighbor-joining tree based on 16S rRNA gene sequence data for Lactobacillus curvatus strain LAB-3H in comparison to the most related Lactobacillus strains based on 16S rRNA partial sequence analysis. 


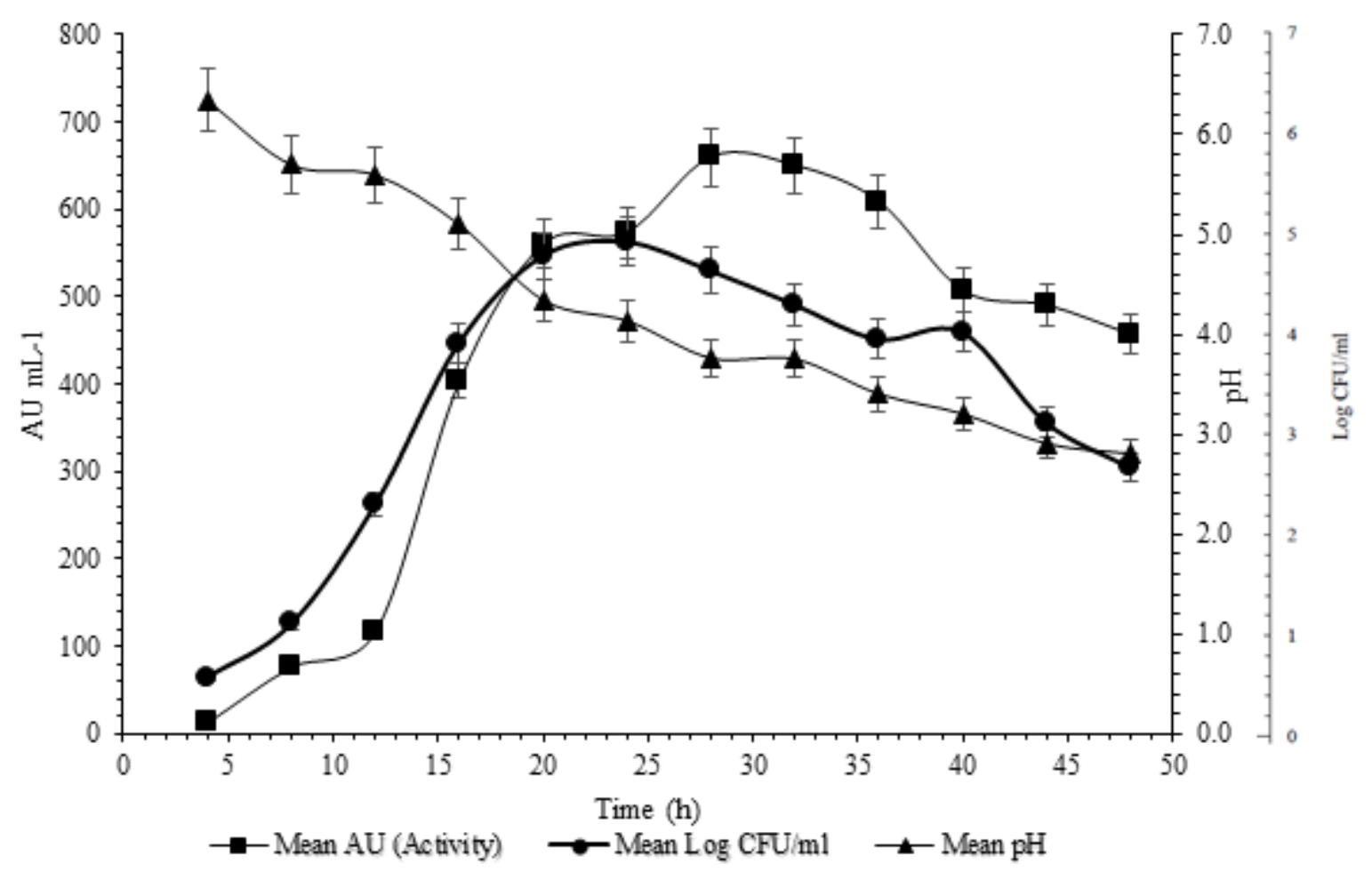

Figure 4

Growth Kinetics of L. curvatus LAB-3H in MRS broth $(\boldsymbol{\square})$ antibacterial activity (AU/ml-1) at 37, ( $)$ Log $\mathrm{CFU} / \mathrm{ml}$, and $(\mathbf{\Lambda}) \mathrm{pH}$. All values are Mean \pm SD of triple determination.

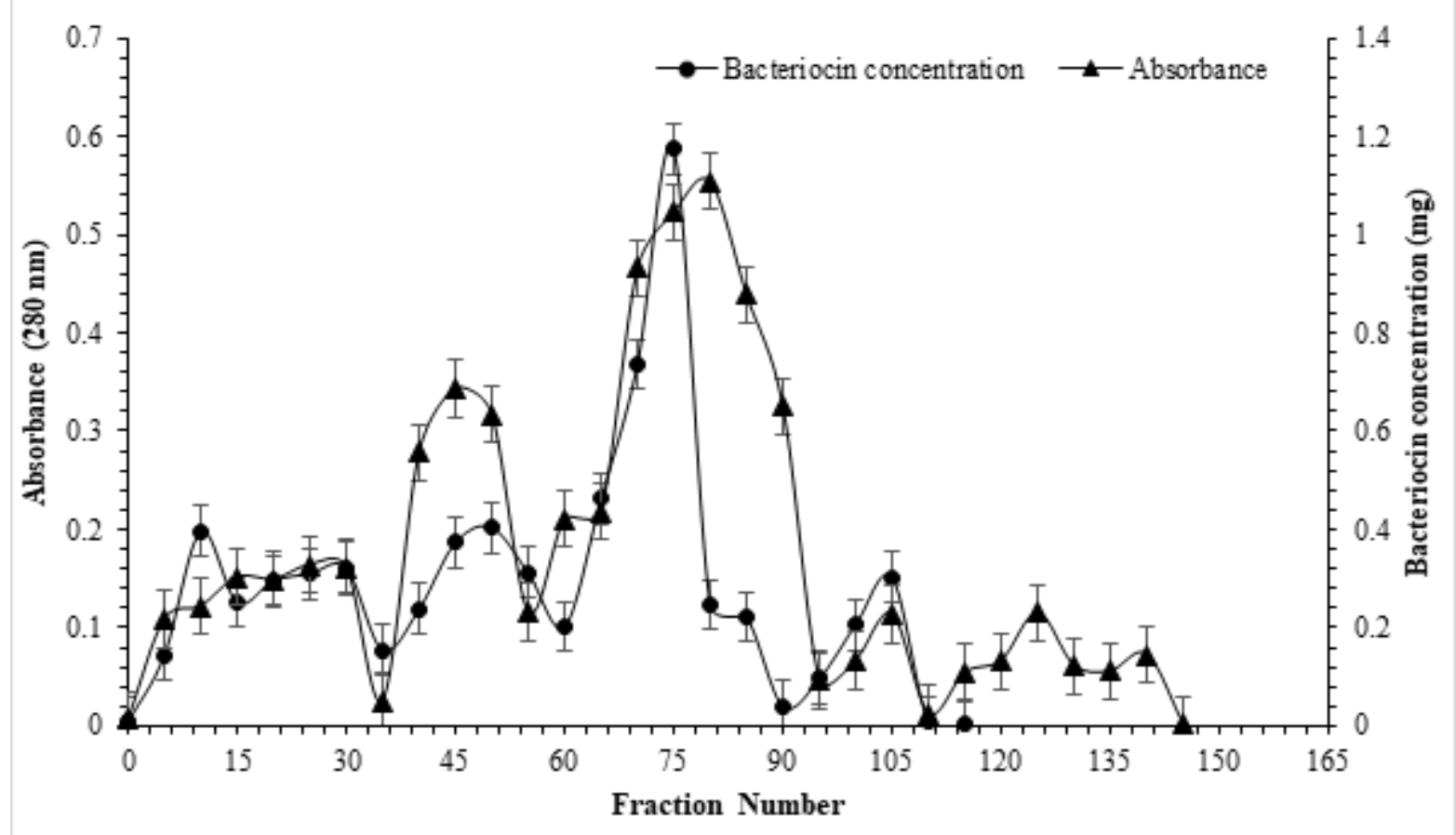

Figure 5 
Elution profile of SP Sepharose Fast Flow column along with bacteriocin concentration produced by L. curvatus LAB-3H.

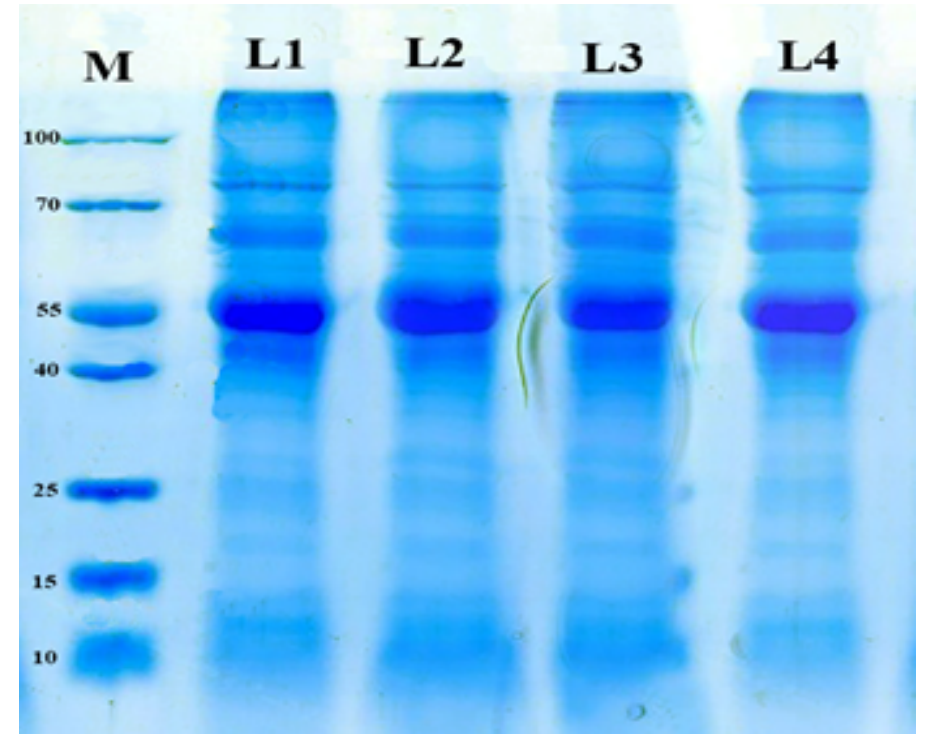

\section{Figure 6}

SDS-PAGE analysis of bacteriocin produced by $\mathrm{L}$. curvatus LAB-3H after the second stage of purification. The lane $(M)$ is the molecular size marker. The lanes, $L 1, L 2, L 3$, and $L 4$ are fractions $65,70,75$, and 80 with the maximum antimicrobial activity, respectively. The molecular size of the bacteriocin is about $55 \mathrm{KDa}$.

\section{Supplementary Files}

This is a list of supplementary files associated with this preprint. Click to download.

- PSR1.pdf

- PSR2.pdf

- PSR3.pdf 